\title{
9. Innovative measures for implementing labour laws and role of labour administration: recent developments in Japan
}

\section{Ryuichi Yamakawa}

\subsection{INTRODUCTION}

This chapter considers new measures relating to the implementation of labour laws in Japan and the role of labour administration with respect to such measures. Although labour administration plays various roles in matters relating to collective as well as individual labour relations, the main role of labour administration is the implementation of labour laws. Labour administration belongs to the executive branch of the government, and the most important role of the executive branch is the implementation of laws that are enacted by the legislative branch. Also, labour administration may formulate labour policies where it is authorized by law and consider how such labour policies can be implemented effectively. In any event, there is no doubt that the implementation of labour laws is a crucial task for labour administration since it is only when labour laws are effectively implemented that their purposes are achieved.

There are various conventional and long-established methods for implementing labour laws, such as criminal punishment, labour inspection, dispute resolution and promotion of voluntary compliance. Considering the importance of the implementation of labour laws, it is necessary to evaluate whether the present measures of implementation are functioning sufficiently well. Changes in the world of work are presenting new challenges for traditional approaches and it is therefore vital to consider the possibility and potential effectiveness of new measures. It may also be necessary to reconsider the content of labour laws to adapt them to new situations. Where this is the case, labour administration must be ready to implement new laws effectively and this might require innovative administrative measures.

Japan provides an interesting example in this respect. As the organization of work has become more complex and forms of non-standard employment 
more widespread, it has become increasingly difficult to establish substantive rules to determine employers' conduct in detail. Thus, as explained in Section 9.3.2.1, an increasing number of statutes contain provisions to require employers to provide measures to achieve policy goals instead of ordering or prohibiting specific conduct. Also, as explained in Section 9.3.2.2, Japan is beginning to utilize legislation that demotes or promotes an employer's reputation in society depending on how they act in relation to labour regulation or desirable policy goals. Such measures are often combined with a new type of legislation that, as explained in Section 9.3.2.5, requires employers to establish action plans to improve aspects of their approach to people management. Labour administration plays an important role in these measures.

The search for new ways of implementing labour laws and policies and encouraging compliance is, of course, also taking place in other countries. For example, the United States has developed legislative provisions to promote awareness of labour regulation through requiring employers to put up posters of labour statutes at each workplace as well as provisions to promote utilization of dispute resolution procedures as a measure to achieve public interests. Meanwhile, in the United Kingdom, there has been a growing use of "naming and shaming" measures to encourage compliance with minimum wage regulations and encourage employer action in relation to issues such as the gender pay gap (e.g. Dickens, 2012). Also, the use of new technologies by labour administration facilitates sharing of information concerning labour laws and the behaviour of individual companies and this has the potential to substantially enhance compliance-oriented measures.

It is against this background that this chapter considers new measures for the implementation of labour laws and the role of labour administration in this respect. Section 9.2 of this chapter briefly describes the traditional measures for the implementation of labour laws. Section 9.3 examines the need for new measures for implementing labour laws in light of current legislative and administrative developments. The conclusion in Section 9.4 reflects on the future prospects for new measures as well as the need for further research and comparative evaluation. Although this chapter focuses on recent developments relating to Japanese labour law and administration, ${ }^{1}$ a brief reference is made with respect to the situations in the United States and United Kingdom, since, as stated above, there have been interesting and informative developments in these countries regarding methods for implementing labour policies. 


\subsection{TRADITIONAL MEASURES OF IMPLEMENTATION OF LABOUR LAWS}

\subsubsection{Criminal Punishment}

Although the situation varies according to country, statutes relating to basic working conditions, such as minimum wages and maximum working time as well as workers' health and safety, can be enforced through criminal punishment. In Japan, the Labour Standards Act and the Industrial Safety and Health Act contain provisions for criminal punishment. " "Labour Inspectors", specialized national civil servants who are employed by the Ministry of Health, Labour and Welfare, are responsible for enforcing these Acts. Labour Inspectors have the same authority as police officers with respect to arrest, search, seizure and examination of objects, in addition to administrative authorities for inspection as stated below. However, authority for indictment and prosecution in criminal procedures rests with prosecutors.

In practice, criminal prosecution does not often take place in Japan, since Labour Inspectors only send serious cases to the prosecutors' offices. In 2018, only 896 cases regarding the violation of the Labour Standards Act and other related statutes were sent to the prosecutors' offices, while Labour Inspectors found 102,242 violations of these statutes as a result of inspection (Kosei-Rodo Sho, 2018a: 12-17, 23). In most cases, Labour Inspectors make an administrative recommendation for the correction of violation (as discussed below) rather than sending the cases to the prosecutor's office. In this sense, administrative recommendations of Labour Inspectors play a more important function not only in promoting voluntary compliance but also in securing the correction of violation under labour laws. This situation reflects the fact that criminal sanction is not always an adequate means of implementing labour laws, since it does not necessarily recover losses to workers caused by the violation. Also, it is sometimes difficult in criminal proceedings to prove beyond doubt that a violation has occurred.

\subsubsection{Administrative Enforcement, Recommendation and Assistance for Compliance}

\subsubsection{Administrative inspection and recommendation for correction}

Generally speaking, labour inspection is an important aspect of the system of labour law enforcement, especially in relation to individual labour laws. However, the subject matter of labour inspection varies from country to country (Von Richthofen, 2002: 29). Matters that are handled by a labour inspectorate in some countries may be beyond the traditional scope of labour 
inspection and left to civil dispute resolution in other countries. In Japan, Labour Inspectors have jurisdiction over a wide range of individual labour laws (Rychly, 2018: 42). For example, payment of wages and limitations on working time are regulated by the Labour Standards Act and these matters are handled by Labour Inspectors, in addition to such matters as workers' health and safety under the Industrial Safety and Health Act and payment of minimum wages under the Minimum Wage Act. This is also the case in the United States, while the United Kingdom has investigation and enforcement administrative systems for specific issues, such as health and safety and minimum wages, instead of general labour inspectorate. In Japan, with respect to the matters where Labour Inspectors do not have jurisdiction, other departments of labour administration have authority to provide administrative guidance under relevant provisions of labour laws. For example, the Employment Environment and Equal Employment Department of the Prefectural Labour Bureaus has authority to provide administrative guidance under several labour laws, such as the Act for Equal Employment Opportunity for Men and Women (Equal Employment Opportunity Act) (Rychly, 2018: 13).

In Japan, Labour Inspectors play a very important role in respect of matters over which they have jurisdiction. ${ }^{3}$ They conduct scheduled inspections, complaint-based inspections and re-inspections to ascertain whether problems have been rectified. If Inspectors uncover a violation of laws which they have a duty to enforce, they usually recommend that the employer corrects the violation. ${ }^{4}$ Although this administrative recommendation for correction of violation does not have binding power in itself, employers usually comply with it since, if they do not comply, the Inspectors can ask the prosecutor's office to initiate a criminal procedure. For example, Labour Inspectors conducted 136,281 scheduled inspections in 2018 (Kosei-Rodo Sho, 2018a: 12-17). As a result of these inspections, violations of the relevant statutes were found at 68.2 per cent of the inspected workplaces. In addition, 20,945 inspections were conducted based on workers' complaints in 2018. The violation rate relating to all types of labour inspection from 2003 to 2018 is shown in Table 9.1. More than 100,000 administrative recommendations have been made in recent years. As stated above, the number of cases where criminal prosecutions take place is much smaller.

Such administrative enforcement by Labour Inspectors can benefit more workers than judicial enforcement through dispute resolution procedure. This is because adjudication under a civil dispute resolution procedure has legal effect only for parties to the procedure, while Labour Inspectors can recommend that employers correct a violation that affects all workers in the workplace. Even so, there is much room for improvement in terms of voluntary compliance with Japanese labour laws. As shown in Table 9.1, violations have been found at nearly 70 per cent of the workplace where scheduled inspections 
Table $9.1 \quad$ Violations found as a result of labour inspection

\begin{tabular}{llll}
\hline Year & Scheduled inspections & Other inspections & $\begin{array}{c}\text { Violations found in scheduled } \\
\text { inspections (\%) }\end{array}$ \\
\hline 2003 & 121031 & 43474 & 65.6 \\
\hline 2004 & 122793 & 42835 & 67.1 \\
\hline 2005 & 122734 & 41407 & 66.3 \\
\hline 2006 & 118872 & 42186 & 67.4 \\
\hline 2007 & 126499 & 42234 & 67.9 \\
\hline 2008 & 115993 & 43097 & 68.5 \\
\hline 2009 & 100535 & 46325 & 65.0 \\
\hline 2010 & 128959 & 45574 & 66.7 \\
\hline 2011 & 132829 & 42703 & 67.4 \\
\hline 2012 & 134295 & 39225 & 68.4 \\
\hline 2013 & 140499 & 23408 & 68.0 \\
\hline 2014 & 129881 & 22430 & 69.4 \\
\hline 2015 & 133116 & 22312 & 69.1 \\
\hline 2016 & 134617 & 21994 & 66.8 \\
\hline 2017 & 135785 & 21361 & 68.3 \\
\hline 2018 & 136281 & 20965 & 68.2 \\
\hline
\end{tabular}

Source: Kosei-Rodo Sho (2018a: 9); Kosei-Rodo Sho (2018b: 114).

were conducted. Although this indicates that Japan's labour inspection system functions adequately, since one of the major roles of the inspection system is the discovery of violations, it also indicates that non-compliance remains a substantial problem.

\subsubsection{Assistance and incentives for achieving policy goals}

In addition to the enforcement of mandatory provisions, Japanese labour laws have often utilized measures to assist employers to achieve policy goals that are defined under certain labour laws. One of the typical measures for such assistance is financial subsidies from the government. For example, the Employment Insurance Act and its enforcement regulation provide a so-called "employment adjustment subsidy" to employers if they avoid economic dismissals by taking such measures as conducting training, arranging a transfer to a related company or paying "leave allowances" to redundant employees who have no work at hand (Hanami et al., 2015: 137-8). This subsidy is intended to give an economic incentive for employers to avoid economic dismissals, although the Act does not directly require employers to avoid economic dismissals or to carry out alternative measures. The main budget source for this 
subsidy is employers' monthly contributions to the Employment Insurance administered by the Ministry of Health, Labour and Welfare. A variety of such financial subsidies are provided by Japanese labour laws, mainly in the area of labour market law. Many of them are based on the Employment Insurance Act.

Thus, labour administration in Japan plays a major role in the implementation of financial subsidies as a measure to achieve labour policies such as the promotion of stability of employment.

\subsubsection{Enforcement through Civil and Administrative Dispute Resolution}

Labour laws can also be enforced as a realization of a private party's legal rights through a dispute resolution procedure. The resolution of labour disputes may be handled by ordinary courts, specialized labour courts or administrative agencies that provide alternative dispute resolution. In Germany, for example, the labour courts play a major role in resolving labour disputes, while the United Kingdom has a combined system of judicial and administrative dispute resolution bodies (Employment Tribunals and the Advisory, Conciliation and Arbitration Service (ACAS)). Although the United States does not have specialized labour courts, administrative agencies handle specific subject matters such as unfair labour practices, which are handled by the National Labour Relations Board (NLRB). Also, the Equal Employment Commission (EEOC) in the United States engages in conciliation and mediation in employment discrimination cases.

Japan currently has both judicial and administrative dispute resolution procedures. ${ }^{5}$ Formerly, an ordinary civil procedure was available for individual and collective labour disputes while the procedures of the Labour Relations Commissions (national and local tripartite administrative agencies) dealt with collective labour disputes by adjudicating in unfair labour practice cases as well as providing conciliation, mediation and arbitration. Due to the increase in the number of individual labour disputes, however, Japan has created two special procedures for resolving them.

Thirty years ago, the number of labour cases litigated in court was very small in Japan. In 1991, only 1,054 civil cases (662 ordinary procedure cases and 392 temporary relief cases) involving labour disputes were filed in district courts (Saiko Saibansho Jimu Sokyoku Gyoseikyoku, 1992: 121). Since then, however, such cases have considerably increased (Figure 9.1) (Saiko Saibansho Jimu Sokyoku Gyoseikyoku, 2019: 1668). Thus, the Labour Tribunal procedure was introduced in 2004 as a simple and fast judicial procedure for resolving individual labour disputes. In 2018, the number of complaints filed with district courts reached 7,126 (3,496 ordinary civil procedure cases and 3,630 Labour Tribunal cases). While the average time for resolving 
labour disputes through ordinary civil procedure at the District Courts is about 14 months, the average time for resolving labour disputes through the Labour Tribunal procedure was around 75 days in 2018.

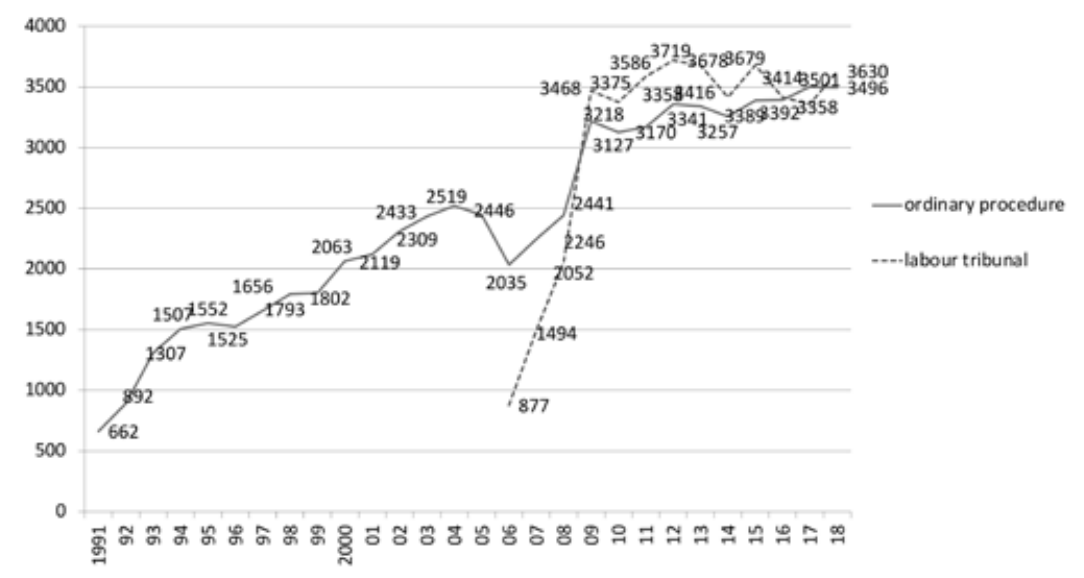

Figure $9.1 \quad$ Number of civil labour cases received by district courts

Also, prior to the establishment of the Labour Tribunal procedure, the Act on Promoting the Resolution of Individual Labour Disputes of 2001 established an administrative alternative dispute resolution system for individual labour disputes. ${ }^{6}$ More specifically, the Act established a Dispute Adjustment Commission in each Prefectural Labour Bureau of the Ministry of Health, Labour and Welfare. This Commission provides a free-of-charge conciliation service to promote voluntary resolution of individual labour disputes. The conciliation by the Commission is a very fast procedure: approximately 90 per cent of the cases are closed within two months from the time of filing. ${ }^{7}$ Since most employees engage in a conciliation procedure before the Commission without relying on representation by lawyers, this procedure can be used by atypical employees such as part-time workers to resolve disputes regarding relatively small amounts of pay. The procedure is, therefore, more accessible for workers. Indeed, the Bureau received 5,123 petitions for conciliation in $2017 .{ }^{8}$ Thus, providing administrative alternative dispute resolution (ADR) procedures is one of the roles of labour administration in the effective implementation of labour laws.

Nevertheless, the civil and administrative dispute resolution procedures have limitations from the viewpoint of the implementation of labour laws. For example, the dispute resolution procedures do not begin unless parties to the 
dispute file a complaint with a court or a Dispute Adjustment Commission, while administrative agencies such as Labour Inspectors may exercise administrative power in their own initiatives. Also, as stated above, the upholding of employment rights is usually limited to workers who become parties to the procedure.

\subsection{NEW MEASURES TO IMPLEMENT LABOUR LAWS AND POLICIES}

\subsubsection{Background: The Need for New Measures}

As discussed above, there is much room for improvement regarding employers' voluntary compliance with labour laws. Furthermore, it is not clear whether enforcement measures against employers who violate labour laws are sufficient as remedies and deterrence measures. More stringent enforcement could in theory be achieved through an increase in the number of Labour Inspectors and the imposition of harsher penalties. However, the tight government budgets of recent years mean that a substantial increase in the employment of Labour Inspectors is unlikely. Moreover, some of the problems regarding enforcement and compliance may be caused by the increasingly complex nature of employment relationships ${ }^{9}$ and firms' approaches to organizing production and service delivery. As a result of management strategies such as subcontracting and outsourcing, the traditional notion of an employment relationship is being challenged (Weil, 2014). It is often difficult to apply and enforce traditional labour laws in such contexts. In order to precisely define the conduct that should be prohibited, the statutory provision would also need to be very complicated and might create opportunities for escaping from regulation. In other words, the "command and control" approach of labour law implementation is no longer sufficient ${ }^{10}$ and new measures need to be considered.

In considering new means of implementation, the compliance and prevention of violations should be emphasized more than sanctions against violations or compensation for victims, which can be provided only after violations actually occur (Yamakawa, 2016b). The costs associated with issuing sanctions and compensation are generally higher than the cost of prevention. Moreover, compensation is not always adequate from the perspective of the workers involved. In addition to the cost and burden of the civil procedure, including the payment of attorney fees, it is sometimes difficult for workers to obtain full recovery once the damage is inflicted. The prevention of violation is also desirable in light of maintaining continuous employment relationships. Of course, schemes for sanction and compensation are still important, since a complete prevention is practically impossible and strong systems for sanction and com- 
pensation will deter violations. Thus, it is important to strike an appropriate balance between sanction/compensation and prevention.

\subsubsection{Implementation of Labour Laws and Policies through New Measures}

Against the background as stated above, new measures for the implementation of labour laws and policies are worth considering. Such new measures have already been introduced in relation to certain labour matters, although their theoretical significance has not been fully recognized or analysed to date. The chapter now turns to examine these issues.

\section{3.2.1 "Duty to provide measures"}

In recent years, labour laws in Japan have often utilized a new legal norm to promote labour law policies. This legal norm requires employers to put in place measures to achieve goals specified by labour laws rather than obligating employers to achieve such goals themselves. Traditionally, such schemes have been utilized in the regulation of workplace safety and health. The Industrial Safety and Health Act in Japan has a number of provisions that obligate employers to provide measures to avoid specific problems relating to workers' safety and health. For example, employers are required to take necessary measures for preventing dangers related to places from which workers could fall or where there are concerns about slides of sand or earth. ${ }^{11}$ The employer's duty under such provisions are called the "employer's duty to provide measures".

In recent years, this "duty to provide measures" has been utilized in a more innovative manner. One of the most significant examples is the employer's duty to provide measures to deal with problems of workplace harassment. In Japan, workplace harassment such as sexual harassment is not directly prohibited. Since harassments are often conducted by supervisors and co-workers, prohibition of harassments against employers are insufficient. Although workplace harassments may constitute torts under the Civil Code and provide for damage liability regarding harassers as well as employers by way of vicarious liability, such relief is limited to monetary compensation only after harassment actually takes place. Also, tort liability under the Civil Code depends on the totality of circumstance in each case, and it is often difficult to determine whether the harassment in question is impermissible conduct.

Thus, the 2007 amendment of the Equal Employment Opportunity Act ${ }^{12}$ introduced a provision that requires employers to take measures to prevent and resolve disputes regarding sexual harassment in the workplace. The contents of the duty, which are specified by the guideline issued by the Ministry of Health, Labour and Welfare, are threefold: (1) to set up and clarify policies to prohibit sexual harassment, (2) to establish consultation and grievance procedure for 
employees, and (3) to carry out appropriate steps such as investigation and disciplinary action when a harassment actually takes place.

Through this scheme, employers are required to take preventive measures for sexual harassment, including promulgation of anti-harassment policy and consultation/grievance procedure. It is difficult to require employers to take such measures through judicial relief. Also, while judicial relief for sexual harassment is usually limited to individual plaintiffs, this scheme can provide benefits for all employees at the workplace once the employer carries out its duty. Moreover, while the determination of tort liability can often become difficult, depending on the circumstances of each case, determination of violation of this duty is easier, since the duty is simply to take measures specified by the Act and the guideline. For example, if an employer fails to establish a policy to prevent sexual harassment, this failure itself constitutes a violation of the employer's duty under the Act, and the Minister of Health, Labour and Welfare (Chief of Prefectural Labour Bureau by delegation) can provide administrative recommendation to correct the violation.

Thus, this scheme requires employers to establish rules and procedures to protect all of their employees. The 2016 amendment of the Equal Employment Opportunity Act includes a similar provision that requires employers to provide measures against "maternity harassment" relating to maternity leave and situations relating to childbirth. The 2016 amendment of the Act on the Welfare of Workers Who Take Care of Children or Other Family Members Including Child Care and Family Care Leave (Child Care and Family Care Leave Act) ${ }^{13}$ similarly includes provisions regarding harassment relating to the exercise of workers' right to provide child care and elder care. Furthermore, in June 2019, the Parliament of Japan amended the Act for the General Promotion of Labour Policy to include a provision that requires employers to provide measures against "power harassment", that is, harassment through the abusive exercise of supervisor's power. ${ }^{14}$

In addition to matters connected with harassment and safety and health in the workplace, labour legislation that contains the "duty to provide measures" provision has been increasing in Japan. For example, the 2007 amendment of the Part-Time Worker's Act (currently the Part-Time and Fixed-Term Workers' Act) created a provision that requires employers to adopt measures to promote part-time workers to the position of regular workers through such means as the notification of opportunity for application for the hiring of regular workers as well as the establishment of an examination system for part-time workers who hope to be promoted to regular workers.

Labour administration plays an important role in the implementation of these provisions since the contents of measures to be taken are usually defined in detail by administrative regulations and are usually enforced through admin- 
istrative guidance and recommendation, as well as the public notification of the employer's name, as explained below.

\subsubsection{Promotion of recognition and monitoring through market mechanism}

Notification to the general public of the name of employers who violate labour laws is intended to serve as a sanction against violation, on the assumption that such a notification will damage an employer's reputation. "Naming and shaming" systems thus provide employers with an incentive to comply with labour laws. Such systems have been utilized in a number of countries, especially in the realm of regulation of safety and health as well as minimum wages. In the United Kingdom, for example, the violation of minimum wage legislation is publicly announced by the Department for Business, Energy \& Industrial Strategy (BEIS), based on information from the "Her Majesty's Revenue and Customs", ${ }^{15}$ which enforces minimum wage laws.

An increasing number of Japanese labour laws have adopted such notification schemes in recent years. The subject matters of such schemes have become much wider than safety and health and minimum wages. Indeed, in addition to the Industrial Safety and Health Act, ${ }^{16}$ the Act on Employment Promotion of Persons with Disabilities ${ }^{17}$ the Act for Equal Employment Opportunity for Men and Women, ${ }^{18}$ the Act for Stability of Employment of Elder Persons, ${ }^{19}$ the Child and Family Care Leave Act, ${ }^{20}$ the Part-time and Fixed-Term Workers' Act, ${ }^{21}$ and the Worker Dispatching Act ${ }^{22}$ all have provisions for "naming and shaming".

One of the earliest such notification schemes was introduced under the Act on Employment Promotion of Persons with Disabilities in its 1976 amendment. The Act currently requires employers in the private sector to employ workers with disabilities so that they account for at least 2.3 per cent of all of their employees. If an employer violates this provision, the Minister of Health, Labour and Welfare directs the employer to establish an action plan to improve the situation. If the employer does not abide by this direction, the Minister may publicize the employer's name on the website of the Ministry of Health, Labour and Welfare. ${ }^{23}$ Although the notification scheme under the Equal Employment Opportunity Act had not been utilized since its introduction in 1997, the Minister of Health, Labour and Welfare announced in September 2015 the first notification of employers who violated the Act. ${ }^{24}$ This notification was widely broadcast on TV news and drew much attention from the public.

In recent years, Japanese labour law has introduced a new method of implementing labour policies by enhancing the public reputation of employers who take desirable measures in view of labour policies. For example, the Act on Advancement of Measures to Support Raising Next-Generation Children ${ }^{25}$ permits an employer to use a special symbol, shown in Figure 
9.2, when the Minister of Health, Labour and Welfare certifies that the employer's action plan to support employees in undertaking child care is appropriate and meets the requirements under the Act. ${ }^{26}$ This sign is called "Kurumin", which means a cover for wrapping babies. Permitting an employer to use this symbol may serve to enhance its reputation. The Act on the Promotion of Female Participation and Career Advancement in the Workplace ${ }^{27}$ and the Act for the Promotion of Youth Employment ${ }^{28}$ operate similar schemes. Under the Act for the Promotion of Youth Employment, employers who have been provided with certification can also receive active support from the Public Employment Offices for their recruiting activities, including invitations to job fairs.

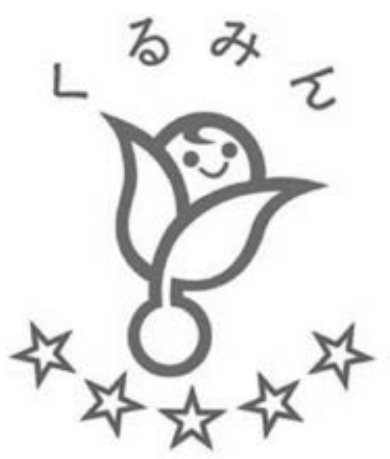

Source: Ministry of Health, Labour and Welfare (Japan).

Figure $9.2 \quad$ "Kurumin” sign

Requiring employers to disclose information to the public can also provide a means of monitoring employers' working conditions or compliance with labour laws (Estlund, 2011: 351). In Japan, as stated above, the Act on the Promotion of Female Participation and Career Advancement in the Workplace obligates employers to draw up and publicize action plans to promote their female employees' active participation in employment, including promotion to managerial positions. ${ }^{29}$ The Act also requires employers to publicize information on the situation of their female employees through the internet or other measures..$^{30}$ This public notification scheme makes it easier for jobseekers, especially female jobseekers, to gather information concerning the situation of women employed by their prospective employers and use this information 
when deciding whether to apply to particular employers. Meanwhile, employers who want to attract talented female jobseekers will be incentivized to improve the situation of their female employees. In this sense, this scheme may enhance the monitoring function of the labour market regarding employers' efforts to support female employees' active participation.

However, since the Act did not specify the information that employers must disclose to the public until recently, employers were free to choose and could avoid publicizing information that might not be attractive to jobseekers. In this sense, it was necessary to require employers to disclose the information that is considered to be important in the labour market so that the monitoring function of the labour market can function effectively. Indeed, the Parliament amended the Act in 2019 so as to require employers to disclose specific information regarding opportunities for career development and work-life balance. ${ }^{31}$ Also, this amendment contains a provision to enable the Ministry of Health, Labour and Welfare to issue an administrative recommendation against employers who disclose false information.

Similar schemes have been introduced in other countries, especially regarding pay equity between men and women. In the United Kingdom, for example, employers with 250 or more employees are obliged to publicly report differences in pay between men and women and other related information on their own websites, as well as on the government-sponsored website under the Equality Act 2010 (Gender Pay Gap Information) Regulations 2017.32

Conversely, the promotion of such monitoring can also be carried out by preventing employers who have violated labour laws from effectively recruiting via employment agencies. In 2015, the Act for the Promotion of Youth Employment introduced a scheme that permits the Public Employment Offices to refuse to post job vacancies offered by employers who violate certain labour laws. ${ }^{33}$ This policy was a response to concerns relating to the poor working conditions experienced by some young workers (new graduates) employed by law-violating employers (referred to as the "black enterprises", Konno, 2012).

The 2017 amendment of the Employment Security Act $^{34}$ considerably enhanced the scheme of inhibiting the labour market access of employers who violate labour laws by extending it to private employment agencies. In addition, while the scheme under the Act for the Promotion of Youth Employment is limited to the recruitment of young jobseekers, the amendment of the Employment Security Act covers recruitment of workers in general. Thus, Japan is beginning to promote the monitoring functions of the labour market through increasing recognition of "good" employers as well as by making it difficult for "bad" employers to advertise vacancies in the labour market. 


\subsubsection{Promoting awareness and understanding of labour law}

One of the most fundamental premises for the implementation of labour laws is that both employers and workers are familiar with labour laws. A number of measures have already been taken for the purpose of promoting understanding of labour law. For example, information has been disseminated by labour administration bodies in various forms including publication of books, distribution of brochures, putting up posters in public places, introduction on websites and conducting free seminars. The Ministry of Health, Labour and Welfare has also begun to promote labour law education for students in order to prepare them for their working lives. For this purpose, the Ministry published and distributed a model programme of labour law education to high schools in $2016^{35}$ and a manual for teaching labour laws to colleges, junior colleges and vocational schools in $2017 .{ }^{36}$ In addition, a non-profit organization in Japan recently established a programme called "Work Rule Kentei (examination)", ${ }^{37}$ which provides for general citizens to be examined about the basic contents of labour laws to receive a certificate if they pass. Although this is a voluntary programme, the Japan Trade Union Congress supports the programme and encourages its members to take the examination. Since such programmes are carried out in collaboration with the educational institutions and non-profit organizations, these developments can be regarded as examples of collaboration in terms of "raising awareness of sustainable development goals" contained in the Principles of Effective Governance for Sustainable Development endorsed by the United Nations (UN) Economic and Social Council in 2018.

In addition to raising the awareness of the general public, dissemination of information about rules under labour laws is also important at the level of the workplace. The Labour Standards Act of Japan has a provision that requires employers to take measures to make their employees aware of the essence of the Act, its enforcement and rules at the workplace by distributing documents to each employee, placing them at conspicuous places in each facility, and making them readable on computers that are easily accessible. ${ }^{38}$ Dissemination of information about legal rules and work rules at workplaces is important and while managers and employees are strongly required to be aware of rules under labour laws at their workplaces, they are generally less knowledgeable than HR managers or union officers. However, since the mere "placing" may satisfy this requirement under the Labour Standards Act, employees are often unaware of the contents of the Act or the rules that are applicable to their workplaces. Thus, it is worthwhile considering more effective means of dissemination.

The situation in the United States is informative in this respect. A number of statutes regulating employment relations require an employer to put up posters at each workplace. Regarding federal labour laws, the Department of Labour (the Equal Employment Opportunity Commission in the case of 
anti-discrimination law) provides sample posters, which are readily available on the website of the Department. ${ }^{39}$ The posters outline the basic contents of each statute and include the phone number of the government office in charge of its administration as well as its URL address, as shown in Figure 9.3.

The role of labour administration in promoting awareness and understanding of labour laws is not limited to unilateral dissemination of information. Labour administration may also establish an interactive system of consultation and assistance for workers to understand labour laws and deal with their problems in the workplace.

In Japan, as stated above, the Act on Promoting the Resolution of Individual Labour Disputes of 2001 established free information and consultation services regarding individual labour disputes at each Prefectural Labour Bureau. This service provides information about labour laws, conducts consultations on the resolution of individual labour disputes, and, if necessary, refers the case to the Dispute Adjustment Commission for conciliation. This system is now widely utilized. Regarding information on labour laws, 1,104,758 requests for information and consultation were made in 2017. Also, 253,005 requests were received in 2017 for consultation in relation to individual labour disputes. ${ }^{40}$

A further example is provided by the United Kingdom, which in 2009 established the Pay and Work Rights Helpline. This is an information and consultation service by free telephone calls regarding a wide range of workplace issues. This Helpline is currently provided by the ACAS as the ACAS Helpline. ${ }^{41}$

\subsubsection{Encouragement of using dispute resolution procedure to promote public interest}

As stated above, the resolution of labour disputes between private parties can play a role in implementing labour laws, especially when rights are enforced as a result of dispute resolution. Thus, dispute resolution can contribute to the realization of public interests with respect to labour laws that consist of public orders such as equal employment opportunities and minimum working conditions. In view of the public nature of the resolution of labour disputes, there is value in establishing schemes to encourage an active use of dispute resolution procedure.

There are a number of potential ways to encourage the use of dispute resolution procedures. One is to provide an economic benefit for workers who prevail in the dispute resolution procedure. For example, under the Fair Labour Standards Act in the United States, a plaintiff who prevails in an action for overtime wages and minimum wages may seek liquidated damages equal to the value of the unpaid wages..$^{42}$ In the same vein, the Labour Standards Act of Japan enables the court in civil cases to order employers to pay double the amount of money that they are obliged to pay under certain provisions of the Act, such as overtime wages. ${ }^{43}$ 


\section{EMPLOYEE RIGHTS UNDER THE FAIR LABOR STANDARDS ACT}

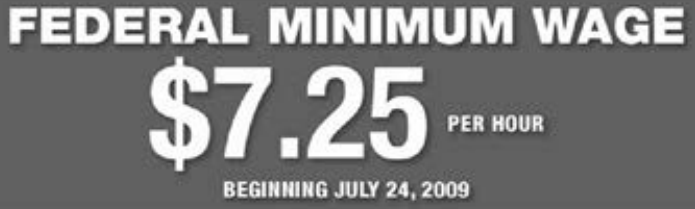

The law requires employers to display this poster where employees can readily see it.

OVERTIME PAY At least 19 times the regular rate of pay lor all hours worked over 40 in a workweek.

CHILD LABOR An omployes must be at least 16 years old to work in mest non-farm jobs and at least 18 to work in nen-farm jobs declared hazardous by the Sescotary of Labor. Youtha 14 and 15 years oid may work outside school hours in various non-manufacturing, non-mining, non-hazardous jobe with certain woek hours restrictions. Different rules apply in agrisultural employment.

TIP CREDIT

Employers of "tipped employees" who meet certain conditions may ctaim a partial wage credit based on tips received by their employess. Employers muat pay tipped employees a cash wage of at least \$2.13 per hour I they claim a tip crods against their minimum wage coligation. If an employee's tips combined with the employer's cash wage of at least $\$ 2.13$ per hour do not equal the minimum hourfy wage, the employer mutt make up the diflerence.

NURSING The FLSA requires employers to peovide ressonable break time for a nursing mother employee MOTHERS who is subiect to the FLSA's overtime requirements in onder for the employes to express breast mik lor her nursing child for one yes aftor the child's bith each time such employes has a need mik for her nutaing child for one yest after the child's birth each time such employes has a need that is shielded from view and free from intrusion from coworkers and the public, which may bo used by the employee to express breash mik.

ENFORCEMENT The Department has autbority to recover back wages and an equal amount in liquidated damages in instances of minimum wage, overtime, and other violations. The Department may litigate and/or recommend criminal prosecution. Employers may be assossed clill money penaities fo each willul or repeated violation of the minimum wage or overtime pay provisions of the law. Civil money penalties may also be assessed for vielations of the FLSA's child labor provisions. Heightened eiva money penaties may be asesssed for each child labor violation that rosults in the death or serious injury of any minor employee, and such assessments may be doubled whan the violations are determined to be wallul of repested. The law albo prohibits retaliating against of discharging workers whe fle a complaint or participate in any peoceeding under the FLSA

ADDITIONAL

- Certain occupations and establiahments are exempt from the minimum wage, andror overtime pay provisions

INFORMATION

- Special peovisions apply to workers in American Samos, the Commonwealth of the Northern Mariana lslands, and the Commonwealth of Puerto Rice.

- Some state laws provide greater employee protections; employers must comply with both.

- Some employers incorrectly classify workers as "independent contractors" when they ave actualy empioyees under the FLSA. it is important to know the difference between the two besause employess funless exemptf are entiled to the FLSA's minimum wage and overtime pay protections and cererecty classified indepandent contractors are not.

- Certain Nal-time studenta, student learners, apprentiens, and workers with dsabirities may be paid less than the minimum wage under special certficates issued by the Department of Labor

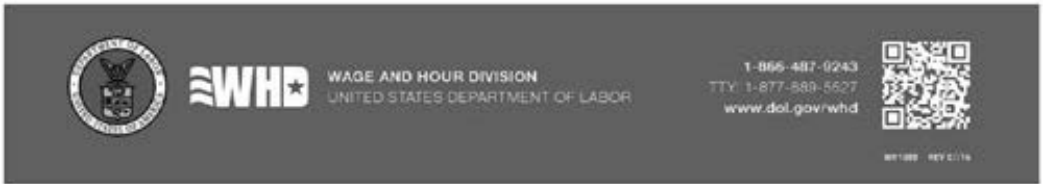

Source: US Department of Labor.

Figure 9.3 Poster of the Fair Labour Standards Law in the United States 
Beyond this, Japanese labour law does not have specific schemes for providing incentives for realizing public interest by way of private litigation, either by courts or administrative agencies. In the United States, there are several other schemes that are intended to promote public interest. For example, prevailing plaintiffs have a right to the payment of attorney fees under public labour and employment laws. In many countries, parties to private litigations must, as a general rule, pay their own attorney fees whether they win or lose. In the United States, however, a number of statutes regarding labour standards and employment discrimination have provisions regarding the payment of attorney fees in the event that workers win their cases. ${ }^{44}$ This is intended to encourage workers to file a suit to realize public interest in view of the fact that workers often lack financial resources to ask attorneys to represent them in litigation.

In addition, under a number of labour and employment statutes in the United States, administrative agencies in charge of their enforcement have a standing right to file a suit against employers who violate such statutes on behalf of the employees who are victims of the employers' violation. For example, the Equal Employment Commission (EEOC) has a right to file a complaint for civil litigation regarding the violation of anti-discrimination statutes such as the Title VII. ${ }^{45}$ Also, under the Fair Labour Standards Act, the US Department of Labor can bring a suit in court on behalf of employees who have rights to recover unpaid overtime and minimum wages. Here, labour administration has a role to implement labour laws by becoming a plaintiff in civil litigation on behalf of aggrieved workers.

\subsubsection{Requirement, regulation and assistance of self-regulation}

The traditional framework of labour law regulation is for the government to establish substantive legal rules and require employers to comply with them. Here, the norms with which employers shall comply are set forth under the law. However, as the reality of workplaces and subject matters of regulation has become more complex in the modern society, it has become more difficult to establish norms that are sufficient to address all potential problems in all workplaces.

One approach to this difficulty is to allow employers to engage in "self-regulation". This does not mean that employers are free to establish workplace norms as they wish. The law may require employers to establish norms in accordance with certain guidelines. Also, the law may require employers to follow certain procedures and to be held accountable by administrative agencies for the contents of their norms. Since the employer's "self-regulation" is regulated in this sense, it may be called "regulated self-regulation", ${ }^{46}$ or a "reflexive" approach as distinct from "command and control" approach" ${ }^{47}$ In Japan, the Act on Advancement of Measures to Support Raising Next-Generation Children, as introduced above, adopted 
such a framework. ${ }^{48}$ Article 12 of the Act requires employers who employ more than 100 employees to draw up an action plan to make assistance to its employees' child care. This Article also requires employers to submit the plan to the Minister of Health, Labour and Welfare and disseminate it to their employees. Although the Act does not intervene in the contents of the plan, the Minister has issued a guideline regarding the contents of the action plan. ${ }^{49}$ If the Minister determines, based on the employer's application, that the action plan is consistent with the guideline, the plan is certified as appropriate. The employer who obtains this certificate may use the "Kurumin" sign, as explained in Section 9.3.2.2. Furthermore, employers are required to submit this certificate to the government if they apply for certain subsidies for carrying out measures to assist their employees' child care.

The Act on the Promotion of Female Participation and Career Advancement in the Workplace, also as explained in Section 9.3.2.2, uses a similar scheme. Under this Act, employers are required to draw up and disseminate an action plan to promote female workers' active participation in employment. Although the contents of the action plan are generally left to the employer's judgement, some elements including numerical goals must be included. The government issues guidance regarding the contents of the plan and employers are required to submit their plans to the government. In this case, economic incentives given to employers whose plans are certified as appropriate include, as stated above, a certain favourable treatment in competitive bidding for contracts with the government, in addition to the right to use certain signs like the "Kurumin".

These action plan requirements are significant in that they do not require employers to achieve specific results in relation to their female employees. Rather, these requirements provide employers scope to choose how they will improve the situation of their employees. In this sense, this scheme can be classified as an example of the "regulated self-regulation" or "reflexive" approach as distinct from the "command and control" approach as stated above.

However, the action plan requirement under the Act on the Promotion of Female Participation and Career Advancement in the Workplace appears to give employers too much leeway regarding the contents of the action plan, in that employers can freely choose the numerical goals to be achieved. In addition, although the Minister of Health, Labour and Welfare can provide advice, guidance and recommendations regarding the implementation of the employer's obligation, the Act does not contain a provision to provide sanctions against where there is a failure to meet this obligation. ${ }^{50}$ Since appropriate legal regulation is important in order to secure the compliance of the employer's duty of self-regulation, it is necessary to evaluate the effectiveness of the current measures for implementing the employer's duty of self-regulation. 


\subsubsection{Implementation of Labour Policies through Other Measures than Labour Laws}

Although labour law is one of the main measures for implementing labour policies, there are other legal and political measures for achieving objectives related to labour policies. One important measure concerns conditions for government procurement. One of the most famous examples is the Davis-Bacon Act of 1931 of the United States. This Act requires contractors and subcontractors to pay local prevailing wages to their employees on certain federally funded or assisted public works projects. ${ }^{51}$

Similar schemes have been introduced in Japan in recent years. Some local governments have introduced schemes in which employers who have achieved certain goals with respect to assisting the employment of disabled persons or working mothers with children are given a "plus factor" in competitive bidding for government contracts..$^{52}$ A similar scheme is contained in the Act on the Promotion of Female Participation and Career Advancement in the Workplace. As stated above, this Act requires employers to draw up and publish an action plan to promote female workers' active participation in employment. If the plan is certified by the Minister of Health, Labour and Welfare as appropriate, the employer may be given a "plus factor" in competitive bidding for contracts with the national government. In addition, tax law can provide employers with incentives to improve the situation of their employees. In Japan, employers who have increased the employment of workers or have achieved wage increase for their employees are entitled to a certain tax reduction ("employment tax reduction"). ${ }^{53}$ Thus, tax law can also be a measure to promote government policies relating to labour matters.

These examples indicate that it is worth considering the utilization of schemes other than those of labour laws. Some of these may be outside the jurisdiction of labour administration. However, as the department of the government that has main responsibility for labour policies, the labour ministry (or equivalent) should make proposals or encourage other departments to consider measures to promote labour policies when they develop public policies under their mandate, such as government procurement or taxation.

\subsection{CONCLUSION}

Traditional measures for the implementation of labour laws are criminal punishment for violation of laws, inspection and guidance provided by administrative bodies, assistance by way of subsidies, and the resolution of labour disputes between private parties. Labour administration has played a major role in the administration of these measures. However, such traditional measures are often insufficient today due to changes in the structure of the labour 
market and the growth of non-standard employment relationships. Therefore, it is necessary to consider new measures for implementing labour laws more effectively. This task is particularly important for labour administration since the implementation of labour laws is one of its major responsibilities.

Within the realm of labour law, it is worth considering new instruments, such as "duty to provide measures", the promotion of recognition and monitoring in market mechanisms, the enhancement of awareness of labour law, encouraging dispute resolutions between private parties to promote public interest, and requiring and assisting employers' self-regulation and the implementation of action plans. In many of these new measures of implementation, the role of labour administration remains important.

National governments should consider using a mix of traditional measures and new measures, since the effectiveness of these measures may vary depending on a number of factors in each country including the nature of the issue to be addressed, the labour market situation, the role of judiciary and administrative agency and so on. For this purpose, it is necessary to evaluate the effectiveness of each measure and determine the best combination of measures against the background of each country. It is also the role of labour administration to conduct such evaluations as a matter of policy making.

Japan has traditionally emphasized the implementation of labour laws and policies through traditional measures such as labour inspection, administrative guidance, and economic assistance and incentives. However, since violations of labour laws are found in many workplaces in Japan, it has become necessary to consider ways to improve the effectiveness of labour laws and policies. Thus, in recent years, measures such as the public notification of the name of employers who violate labour laws have been introduced. In addition, schemes have been introduced that seek to achieve the goals of labour policies through self-regulation by employers.

Although some of these approaches have also been used in a number of other countries, for example publicizing the names of employers that violate labour laws, other approaches that Japan has adopted are relatively novel and may be worth considering by other countries. For example, the effective implementation of "duty to provide measures" can promote the prevention of disputes and bring benefits for more employees than enforcement based on actual cases of violation. The measures by which employers may enhance their reputation may also be informative, in that this approach has resulted in less resistance from Japanese employers to legislation aimed at improving the situation of employees.

Even so, the effectiveness of such new measures has yet to be evaluated through empirical evidence. Evaluations are therefore needed and are also an important element in the monitoring and evaluation systems that contribute to "sound policy making", which is among the UN's Principles of Effective 
Governance for Sustainable Development. Furthermore, policy making can be informed by the experiences of different countries and it is therefore important that interested countries exchange information and discuss their experiences regarding the measures of implementation of labour laws. Such information exchange and discussion at an international level will contribute to the promotion of effective governance in relation to labour administration.

\section{NOTES}

1. For comprehensive overview of Japanese labour administration and its recent developments, see Rychly (2018).

2. http://www.jil.go.jp/english/laws/documents/l.standards2012.pdf (the Labour Standards Act, Arts. 117-21); http://www.japaneselawtranslation.go.jp/law/ detail $/$ id $=3440 \& v m=04 \& r e=01$ (the Industrial Safety and Health Act, Arts. 115-3-123).

3. For the Labour Inspection System in Japan, see Sakuraba (2013: 35).

4. As regards the prevention of violation of labour laws, Labour Inspectors in Japan provide advice and instruction for employers. They also provide seminar-style guidance for groups of employers. See Rychly (2018: 44).

5. Regarding dispute resolution systems in Japan, see Yamakawa (2013: 899) and Yamakawa et al. (2016a).

6. For the contents and operation of the System for Promoting Resolution of Individual Labour Disputes, see https://www.mhlw.go.jp/stf/houdou/0000213219 .html.

7. In $2017,88.3$ per cent of the cases handled by the Adjustment Commissions were closed within two months. However, the success rate of conciliation, that is, the percentage of cases in which the parties agreed to settle the disputes as a result of conciliation, is less than 40 per cent. See ibid. In 2017, the success rate was 38.3 per cent. One of the reasons for such low success rate is the lack of mechanism to compel the respondent (mostly employers) to participate in the conciliation procedure.

8. Ibid.

9. Regarding the situations in the United States from the viewpoint of the regulation of employment discrimination, see Sturm (2001: 458).

10. Regarding the theoretical situation in the United Kingdom, see Deakin et al. (2012: 119).

11. Article 21, item 2 of the Industrial Safety and Health Act (http://www.ja paneselawtranslation.go.jp/law/detail/?id=1926\&vm=04\&re=01). The contents of the necessary measures are specified by the Enforcement Regulations of the Act.

12. http://www.japaneselawtranslation.go.jp/law/detail/?id $=60 \& \mathrm{vm}=04 \& \mathrm{re}=01$.

13. http://www.japaneselawtranslation.go.jp/law/detail/?id $=2438 \& v m=04 \&$ re $=01$.

14. https://www.mhlw.go.jp/english/policy/children/work-family/d1/20191122e.pdf.

15. https://assets.publishing.service.gov.uk/government/uploads/system/uploads/ attachment_data/file/656568/nmw-enforcement-beis_-_policy_doc_full_vFINA $\bar{L} \_3$ _.pdf.

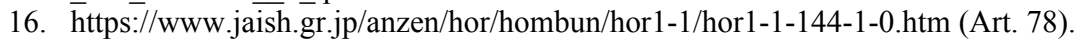

17. http://wwwhourei.mhlw.go.jp/cgi-bin/t docframe.cgi?MODE=hourei\&DMODE $=\mathrm{CONTENTS} \& \mathrm{SMODE}=\mathrm{NORMAL} \& \overline{\mathrm{K}} \mathrm{EYWORD}=\& \mathrm{EFSNO}=1481$ (Art. 47). 
18. http://www.japaneselawtranslation.go.jp/law/detail/?id=60\&vm=04\&re $=01$ (Art. $30)$.

19. http://www.japaneselawtranslation.go.jp/law/detail/? $\mathrm{ft}=3 \& \mathrm{re}=01 \& \mathrm{dn}=1 \& \mathrm{ia}=03 \&$ $\mathrm{bu}=2048 \& \_\mathrm{x}=53 \& \_\mathrm{y}=20 \& \mathrm{ky}=\&$ page $=16$ (Art. 10).

20. http://www.japaneselawtranslation.go.jp/law/detail $/$ id $=2288 \& v m=04 \&$ re $=01$ (Art. 56.2).

21. http://wwwhourei.mhlw.go.jp/cgi-bin/t_docframe.cgi?MODE=hourei\&DMODE $=$ CONTENTS\&SMODE $=$ NORMAL $\& \bar{K} E Y W O R D=\& E F S N O=1654$ (Art. 18).

22. http://www.japaneselawtranslation.go.jp/law/detail $/$ ? $\mathrm{id}=75 \& \mathrm{vm}=04 \& \mathrm{re}=01$ (Art.49.2).

23. In March 2015, the names of eight employers were published. See http://www .mhlw.go.jp/stf/houdou/0000080099.html.

24. http://www.mhlw.go.jp/stf/houdou/0000096409.html.

25. http://www.japaneselawtranslation.go.jp/law/detail/?vm=04\&re $=01 \& \mathrm{id}=1560$.

26. http://www.mhlw.go.jp/stf/seisakunitsuite/bunya/kodomo/shokuba_kosodate/ kurumin/.

27. http://www.japaneselawtranslation.go.jp/law/detail/?ft $=1 \& \mathrm{re}=01 \& \mathrm{dn}=1 \& \mathrm{co}=01$ $\& \mathrm{ia}=03 \& \mathrm{x}=58 \& \mathrm{y}=8 \& \mathrm{ky}=\% \mathrm{E} 6 \% \mathrm{~B} 4 \% \mathrm{BB} \% \mathrm{E} 8 \% \mathrm{BA} \% 8 \mathrm{D}+\% \mathrm{E} 5 \% \mathrm{~A} 5 \% \mathrm{~B} 3 \% \mathrm{E} 6$ $\% 80 \%$ A7\&page $=2$.

28. The Law no. 98 of 1970 , as amended in 2015.

29. Article 7 of the Act, https://www.mhlw.go.jp/web/t_doc_keyword?keyword=\%E5 $\% \mathrm{~A} 5 \% \mathrm{~B} 3 \% \mathrm{E} 6 \% 80 \% \mathrm{~A} 7 \&$ dataId $=73 \mathrm{ab} 4892 \&$ dataType $=0$ \&pageNo=1\&mode $=0$.

30. Article 20 of the Act. Ibid.

31. https://www.mhlw.go.jp/content/000486033.pdf.

32. Although the Equality Act of 2010 introduced a provision of such reporting duty, the coalition government did not put the provision into effect in 2010. But this policy was changed in 2017 , and the above-stated regulations came into force in 2017. Regarding the significance of this public reporting duty, see Hepple (2012: 55-62).

33. Article 15 of the Act. http://www.shugiin.go.jp/internet/itdb_gian.nsf/html/gian/ honbun/houan/g18905050.htm.

34. http://www.japaneselawtranslation.go.jp/law/detail/?id=10\&vm=04\&re=01.

35. https://www.mhlw.go.jp/stf/houdou/0000163136.html.

36. https://www.mhlw.go.jp/stf/houdou/0000204687.html.

37. http://workrule-kentei.jp/.

38. http://www.jil.go.jp/english/laws/documents/l.standards2012.pdf (Art. 106).

39. http://www.dol.gov/oasam/boc/osdbu/sbrefa/poster/matrix.htm.

40. For the operation of the consultation service, see https://www.mhlw.go.jp/stf/ houdou/0000213219.html.

41. http://www.acas.org.uk/index.aspx?articleid=2042.

42. 29 U.S.C. $\S 216(b)$.

43. http://www.japaneselawtranslation.go.jp/law/detail/?ft $=1 \& \mathrm{re}=01 \& \mathrm{dn}=1 \& \mathrm{co}=01$ $\& \mathrm{ia}=03 \& \mathrm{x}=0 \& \mathrm{y}=0 \& \mathrm{ky}=\% \mathrm{E} 5 \% 8 \mathrm{~A} \% \mathrm{~B} 4 \% \mathrm{E} 5 \% 83 \% 8 \mathrm{D} \% \mathrm{E} 5 \% 9 \mathrm{~F} \% \mathrm{BA} \% \mathrm{E} 6 \% \mathrm{BA}$ $\% 96 \% \mathrm{E} 6 \% \mathrm{~B} 3 \% 95$ \&page $=23$.

44. For example, 29 U.S.C. $§ 216$ (b) (Fair Labour Standards Act).

45. 42 U.S.C. $\S 2000 \mathrm{e}-5(\mathrm{k})$.

46. Regarding "self-regulation" and "regulated self-regulation", see Estlund (2010).

47. Regarding the "reflexive" approach of labour law, see Rogowski (2011).

48. http://wwwhourei.mhlw.go.jp/cgi-bin/t_docframe.cgi?MODE=hourei\&DMODE $=\mathrm{CONTENTS} \& S M O D E=$ NORMAL $\& \overline{\mathrm{K}} \mathrm{EYWORD}=\& \mathrm{EFSNO}=1617$. 
49. http://www.mhlw.go.jp/general/seido/koyou/jisedai/kaisei/kaisei-houshin.html.

50. Although the 2019 amendment of this Act enabled the Minister to notify the public regarding the violation of the employer's obligation to disclose information on the situation regarding the female employees (see https://www.mhlw.go.jp/english/ policy/children/work-family/d1/20191122e.pdf), this amendment does not cover the failure to draw up the action plan.

51. 40 U.S.C. $\S 3142$.

52. Regarding the case of the Osaka Prefecture, see http://www.pref.osaka.jp/attach/ 9495/00000000/H22\%201 sougouhyouka.pdf.

53. http://www.mhlw.go.jp/bunya/roudouseisaku/dl/koyousokushinzei_qa.pdf.

\section{REFERENCES}

Deakin, S., McLaughlin, C. and Chai, D. (2012) "Gender Equality and Reflexive Law: The Potential of Different Regulatory Mechanisms", in Dickens, L. (ed.) Making Employment Rights Effective, Oxford: Hart Publishing, pp. 115-37.

Dickens, L. (ed.) (2012) Making Employment Rights Effective, Oxford: Hart Publishing.

Estlund, C. (2010) Regoverning the Workplace: From Self-regulation to Co-regulation, New Haven, CT: Yale University Press.

Estlund, C. (2011) "Just the Facts: The Case for Workplace Transparency", Stanford Law Review, 63 (2), pp. 351-407.

Hanami, T., Komiya F. and Yamakawa, R. (2015) Labour Law in Japan, Alphen aan den Rijn: Wolters Kluwer.

Hepple, B. (2012) “Agency Enforcement of Workplace Equality”, in Dickens, L. (ed.), Making Employment Rights Effective: Issues of Enforcement and Compliance, Oxford: Hart Publishing.

Konno, H. (2012) Black Kigyo (Black Enterprise), Tokyo: Bungei-shunju.

Kosei-Rodo Sho (Ministry of Health, Labour and Welfare) (2018a) Heisei 30 Nen Rodo Kijun Kantoku Nenpo (Annual labour standards inspection report 2018).

Kosei-Rodo Sho (Ministry of Health, Labour and Welfare) (2018b) Heisei 30 Nen-Ban Kosei-Rodo Hakusho (White Paper on Health, Labour and Welfare 2018), Shiryo-hen (materials part).

Rogowski, R. (2011) Reflexive Labour Law in the World Society, Cheltenham, UK and Northampton, MA: Edward Elgar.

Rychly, L. (2018) The Japanese Labour Administration System in the Light of the International Practice. Geneva: ILO.

Saiko Saibansho Jimu Sokyoku Gyoseikyoku (Office of Secretary General, Administrative Division, Supreme Court of Japan) (1992) Heisei 3 Nendo Rodo Kankei Minji-Gyousei Jiken no Gaiyo (Outline of Civil Labour Cases in 1991), HOSO JIHO (Lawyers' Association Journal), 44 (7), pp.1333-75.

Saiko Saibansho Jimu Sokyoku Gyoseikyoku (Office of Secretary General, Administrative Division, Supreme Court of Japan) (2019) Heisei 30 Nendo Rodo Kankei Minji-Gyousei Jiken no Gaiyo (Outline of Civil Labour Cases in 2018), HOSO JIHO (Lawyers' Association Journal), 70 (8), pp.1667-83.

Sakuraba, R. (2013) "Effectiveness of Labour Law and Labour Inspection System in Japan", Kobe University Law Review, 47, pp. 35-50.

Sturm, S. (2001) "Second Generation Employment Discrimination: A Structural Approach”, Columbia Law Review, 101 (3), pp. 458-568. 
Von Richthofen, W. (2002) Labour Inspection: A Guide to the Profession, Geneva: ILO.

Weil, D. (2014) Fissured Workplace, Cambridge, MA: Harvard University Press.

Yamakawa, R. (2013) "Systems and Procedures for Resolving Labor Disputes in Japan", Comparative Labor Law and Policy Journal, 34 (3), pp. 899-927.

Yamakawa, R. (2016a) "Japan", in Ebisui, M., Cooney, S. and Fenwick, C. (eds), Resolving Individual Labour Disputes, Geneva: International Labour Organization, pp. 167-201.

Yamakawa, R. (2016b) "Policy Measures to Tackle Violations of Labor and Employment Laws in Japan”, Japan Labor Review, 13 (4), pp. 106-7. 